\title{
Honorary note: Jan Drzymala - 70th birthday
}

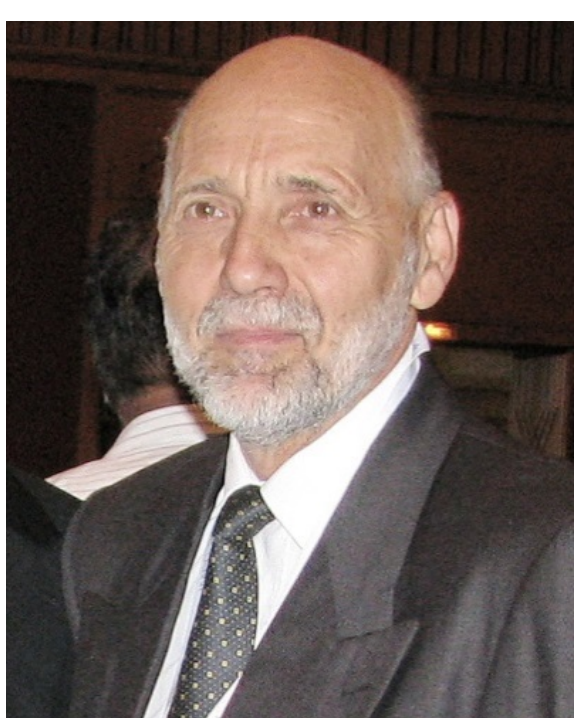

Jan Drzymala was born on September 25, 1949 in Slawa, Lower Silesia/Lubusz Land, Poland. He graduated, with a M.Sc. degree in chemistry, from the Wroclaw University of Science and Technology in 1973 and obtained a Ph.D. degree in mineral processing under the supervision of Prof. J.S. Laskowski in 1977. In 1978/79 he spent 15 months as a Postdoctoral Research Engineer at the Department of Material Science and Mineral Engineering, University of California, Berkeley, USA, working with Professor D.W. Fuerstenau on selective flocculation in the silica/hematite system. Between 1979 and 1984 he was back in Poland and next he spent one year in the USA working on oil agglomeration with Prof. T. D. Wheelock and Dr. R. Markuszewski at the Chemical Engineering Department, Iowa State University, Ames, Iowa. He continued the research on oil agglomeration in Ames in 1988/90 (2 years), 1991 (3 months), 1994 (6 months), and 2000 (3 months). In 2001 he was a Visiting Professor at Laboratoire Environnement et Minéralurgie, Nancy, France (3 months) working with prof. J. Mielczarski. The President of Poland appointed him as a Full Professor in 2002. He has been employed, between 1973 and 2018, by the Wroclaw University of Science and Technology in Wroclaw, Poland. He was teaching undergraduate, graduate and postgraduate students mineral processing and chemistry. As the editor-in-chief of the Physicochemical Problems of Mineral Processing journal he managed to put on the list of journals in the Journal Citation Reports in 2009. He was also a co-editor of several peer-reviewed graduate students conference proceedings devoted to interdisciplinary topics in mining and geology as well as four annual volumes (2014-218) of Kuperschiefer (copper bearing carbonaceous Zechstein shale, in Polish lupek miedzionosny). He wrote a book on mineral processing entitled Foundations of theory and practice of minerallurgy (two editions in Polish, one in English, second English edition is currently in preparation). The first English version is available free of charge at http:// www.dbc.wroc.pl/dlibra/docmetadata?id=2070 \&from=publication. He supervised doctoral dissertations of Jacek Bigosinski, Krzysztof Pradel, Tomasz Ratajczak, Zaklina Konopacka, Hussin A.M. Ahmed, Przemyslaw B. Kowalczuk, wrote 17 doctoral evaluations and several opinions for promotion of Professors. He was a member of the International Advisory Committee of International Mineral Processing Council.

The most important contributions of Professor Jan Drzymala, many accomplished together with his co-workers, are presented below.

Prof. Drzymala got his MSc under the supervision of Prof. Serkies and published his first paper (J. Drzymala, J. Serkies, On the Lechosos Opals and Chrysoprases in the Weathering Zone of Serpentinites from Szklary (Lower Silesia), Bull. Acad. Sci., des Science de la Terrie, XXI, No. 2, 111-117(1973)) showing that green color silicas, occurring in the Szklary (Lower Silesia, Poland) weathering deposit, which were investigated by IR spectroscopy and X-ray techniques, can be present both as nickel-bearing microcrystalline quartz (chrysoprase), which presence was disputable, as well as nickel-bearing (lechosos) opals. After suicidal death of prof. Juliusz Serkies, he joined the newly created, by prof. J.S. Laskowski, mineral processing research and teaching group at the Wroclaw Technical University, working on mineral processing and surface properties of minerals. The result was his Ph.D. degree and publication (J. Drzymala, J. Lekki, J. Laskowski, Surface Dissociation Constants for Solid OxideAqueous Solution System, 1979. Colloid and Polymer Sci., 257, 768-772) in which surface dissociation 
constants of surface hydroxyl groups of selected oxides, based on a thermodynamic derivation taking into account the surface charge/zeta potential of the solid/aqueous solution interface, were calculated.

In 1978 Prof. Drzymala was a postdoc working in the mineral processing group of D.W. Fuerstenau in Berkeley. He worked on separation of silica and hematite by selective flocculation. The results of investigations were published in three papers (J. Drzymala, D.W. Fuerstenau, Selective Flocculation of Hematite in the Hematite-Quartz-Ferric Ions-Polyacrylic Acid System. Part I. Activation and Deactivation of Quartz, Inter. Min. Process. Journal, 8, 265-277(1981); Part 2. Effect of Grinding and a Hydrofluoric Treatment on Selectivity of Flocculation, Int. J. Min. Proc., 129, 1-5, 2014; J. Drzymala, D.W. Fuerstenau, Adsorption of Polyacrylamide, Partially Hydrolyzed Polyacrylamide and Polyacrylic Acid on Ferric Oxide and Silica, Process Technol. Proc., (Flocculation in Biotechnology and Separation Science), 45-60 (1987).

In 1979 he returned from the USA and joined the research group of Dr. Janusz Lekki and Dr. Andrzej Luszczkiewicz, and worked on developing a technology of separation of magnetite from ilmenite and next purification to produce, accepted by industry, ilmenite concentrates from the Polish magnetiteilmenite vanadium-rich ore from Krzemianka, located in northeastern Poland. It was established that the main obstacle to obtained the goal was the presence of hercynite and pleonaste, which were difficult to separate by oleate flotation. The following papers were published (J. Drzymala, A. Luszczkiewicz, P. Simiczyjew, Hercynite-Pleonaste from Ilmenite-Magnetite Rocks of Krzemianka (NE Poland). Miner. Polonica, 13(2), 33-40(1982); J. Drzymala, A. Luszczkiewicz, P. Simiczyjew, Flotation Study on Hercynite High-Hercynite Ilmenite Ore, Inter. Miner. Process. Journal 10, 289-296(183); A. Luszczkiewicz, J. Lekki, J. Drzymala, Difficulties Encountered During Upgrading of Polish Ilmenite-Magnetite Ore, Prace IMN, Gliwice, 3/4, 119-124(1983), in Polish).

To find the way of separation of hercynite from ilmenite and purify ilmenite concentrates it became necessary to look more closely into properties of the oleate-type flotation collectors used for this purpose. The result of individual investigations of Prof. Drzymala was a complete phase diagram of the oleic acid/water/ $\mathrm{NaCl}$ vs. $\mathrm{pH}$ at 25 oC system published in: J. Drzymala, Chemistry of Oleic AcidWater-NaCl System vs. $\mathrm{pH}$ at 25C. Surfactants in Solution, V7, K.L. Mittal Ed., Plenum Press, New York, 483-496 (1990). The diagram shows the areas of oleate ions, molecular forms, micelles and liquid crystals in the system. The surface properties of oleic acid were also investigated and described in J. Drzymala, An Estimation of the Surface Ionization Constant of Oleic Acid in Aqueous Sodium Chloride Solution, Colloid and Polymer Sci., 265, 613-618(1987). All his accomplishments regarding oleate were summarized in a monograph: J. Drzymala, Properties of Oleate Aqueous Solutions and Emulsions, Scientific Papers of IChNiMPR of Wroclaw University of Technology, 61, Monograph 29, 1-89(1990), in Polish. The monograph was used for a partial fulfilment of the requirements to receive the degree of Doctor of Science (D.Sc., habilitation).

In 1984 Prof. Drzymala was invited by Prof. T.D. Wheelock and Dr. Markuszewski to Iowa State University in Ames (USA) to work for a year on application of oil agglomeration for coal cleaning. Altogether he spent in Ames 4 years. The research and cooperation were very rewarding and fruitful. They published several papers on the mechanism of oil agglomeration in model and real agglomerating systems, and on application of pyrite depressants in the agglomerating systems. The important finding was a significant role of air in the process, which was named air-promoted oil agglomeration (J. Drzymala, R. Markuszewski, T.D. Wheelock, Influence of Air on Oil Agglomeration of Carbonaceous Solids in Aqueous Suspension, Inter. Miner. Process. Journal, 18, 277-286(1986); J. Drzymala, T.D. Wheelock, Air Promoted Oil Agglomeration of Moderately Hydrophobic Coals. 2. Effect of Air Dosage in a Model Mixing System, Coal Preparation, 18, 37-52 (1997)). Basing on the experimental observations, a new process was proposed, in which oil was completely replaced by air. The process was named air agglomeration (J. Drzymala, T.D. Wheelock, Air Agglomeration of Hydrophobic Particles, in: Processing of Hydrophobic Minerals and Fine Coal, J.S. Laskowski and G.W. Poling Editors, Canadian Institute of Mining, Metallurgy and Petroleum, Montreal, Canada, 1995). Another innovation was monitoring the course of oil agglomeration by turbidity measurements (J. Drzymala, T.D. Wheelock, Determining the Oil Agglomeration Characteristics of a Coal Suspension by Monitoring Turbidity Changes, 3rd International Conf. on Process. and Utiliz. of High-Sulfur Coals, Elsevier, Amsterdam, 289-300(1990)). The oil agglomeration investigation led to finding that dedecylphenol was a very 
efficient agglomerant for some oxidized carbonaceous materials (J. Drzymala, J.T. Gorke, T.D. Wheelock. A flotation Collector for the Separation of Unburned Carbon from Fly Ash, Coal Preparation, $25,67-80(2005))$.

In 1989, together with Dr. Lekki, a method, called flotometry was invented. The method is based on monitoring flotation of different size fractions of particles for a long time of flotation to find the maximum yield, and next, the maximum size of floating particles. The flotometry method allows to find relationships between different parameters of flotation systems including recovery (yield), hydrophobicity, density, particle size. As a result also a distinction between true floatation and mechanical carryover is possible (J. Drzymala, J. Lekki, Flotometry-Another Way of Characterizing Flotation, J. Colloid Interface Sci., 130, 205-210(1989). J. Lekki, J. Drzymala, Flotometric Analysis of Collectorless Flotation of Sulfide Materials, Colloids and Surfaces, 44, 179-190(1990). He continued the flotometric investigations after Dr. Janusz Lekki left Wroclaw for Silesian Technical University. He published three papers providing relations between flotation parameters (J. Drzymala, Characterization of Materials by Hallimond Tube Flotation. Part 1: Maximum Size of Entrained Particles, Int. J Miner. Process., 42, 139-152(1994); Part 2: Maximum Size of Floating Particles and Contact Angle, Int. J. Miner. Process., 42, 153-167(1994) and erratum 43, 1995, 135; Part 3: Maximum Size of Floating and Interacting Particles, Int. J Miner. Process., 55, 203-218(1999). Many materials were tested by flotometry in the absence of any regents and the results were summarized in the paper of P.B. Kowalczuk, J. Drzymala, Contact Angle of Bubble with Immersed-in-Water Particle of Different Materials, Industrial and Engineering Chemistry Research, 50(7), 4207-4211 (2011). Flotometry was further developed by taking into account the dynamics of the process in different flotation machines using a machine constant. This was considered in a paper together with co-workers (P.B. Kowalczuk, O. Sahbaz, J. Drzymala, Maximum Size of Floating Particles in Different Flotation Cells, Minerals Engineering, 2011, 24(8), 766771(2011)).

The natural flotation and flotometric contact angles of most hydrophobic materials (molybdenite, many sulphides, copper bearing shale) are much smaller than indicated by the sessile drop data. Their full flotation can be realized provided that a frother is used in flotation. It points to a great role of thin films in flotation and flotometric measurement. This issue requires further studies and is being considered by determination of energy barrier and activation energy in separation systems (J. Drzymala, Arrheniusan Activation Energy of Separation for Different Parameters Regulating the Process, Physicochem. Probl. Miner. Process. (Special issue to honor J.S. Laskowski) 54(4):1152-1158(2018)).

Water is essential in mineral processing operations, and hence understanding its interfacial properties, including the ice/water border, is very important. The electrical charge and potential of the ice/water interface play a role not only in mineral processing as a model for the oxide/water system but also in environmental phenomena including weather, especially thunderstorms. Early trials of Schulman and Perreira in 1964 to measure the zeta potential of ice were unsuccessful, until Prof. Drzymala's idea to use heavy ice suspended in water, allowing to create an equilibrium system between 0 and $3.8 \mathrm{oC}$. The idea was positively experimentally verified together with his coworkers and describe in the papers J. Drzymala, Z. Sadowski, L. Holysz E. Chibowski, Ice/Water Interface, Zeta Potential, Point of Zero Charge, and Hydrophobicity, J. Colloid Interface Sci., 220, 229-234 (1999); J. Drzymala, Study of the ice-water interface, Encyclopedia of Surface and Colloid Science, Arthur T. Hubbard (editor), Marcel Dekker, New York,4892-4898 (2002). The properties of the interfacial regions from the thermodynamic point of view were also considered by Prof. Drzymala together with Prof. Lyklema (†2017) for aqueous electrolyte solutions (J. Drzymala, J. Lyklema, Surface Tension of Aqueous Electrolyte Solutions. Thermodynamics, J. Phys Chem. A., 116(25), 6465-72, (2012)).

In mineral processing different methods of separation are used and the results are presented in numerous ways. To put some order in this aspect of mineral processing Prof. Drzymala, together with his at that time Ph.D. student Prof. P.B. Kowalczuk, proposed a system for that in a paper J. Drzymala, P.B. Kowalczuk, A Proposition for Symbolism of Non-ideal Separations Followed by Analytical Separations Used for Evaluation of Separation Efficiency, Mineral Processing and Extractive Metallurgy Review, Processing and Extractive Metallurgy Review, 32, 278-288 (2011). Unfortunately, the system has not been adopted by other researchers and no citations of this paper can be found in the Web of Science. 
Prof. Drzymala proposed many types of graphical representations of separation results and the way to used them to find local and global efficiencies as a well as mathematical forms of separation curves. Although all the curves present the same experimental data, their usefulness is different. It was shown by Prof. Drzymala that recovery-recovery upgrading curve, now called the Fuerstenau curve or plot, is very convenient (J. Drzymala, Atlas of Upgrading Curves Used in Separation and Mineral Science and Technology, Physicochemical Problems of Mineral Processing, Part 1. 40, 19-29 (2006), Part 2., 41, 27-35 (2007), Part 3., 42 (2008) 75-84; J. Drzymala, H.A.M. Ahmed, Mathematical Equations for Approximation of Separation Results Using the Fuerstenau Upgrading Curves, Int. J. Miner. Process., 76, 55-65 (2005). The upgrading curves, especially the Fuerstenau curve, can be also generated by using kinetic data (A. Bakalarz, J. Drzymala, Interrelation of the Fuerstenau Upgrading Curve Parameters with Kinetics of Separation, Physicochemical Problem of Mineral Processing, 49(2), 443-451(2013)).

A great care must be observed when using statistics for evaluation of separation data in the form of separation curve due to different degree of $x-y$ separation results parameters self-similarity. In case of the Fuerstenau plot the self-similarity is low, while for other curves is high (M. Duchnowska, J. Drzymala, Self-similarity of Upgrading Parameters Used for Evaluation of Separation Results, Int. J. Mineral. Processing, 106-109, 50-57(2012)). The upgrading curves are also useful for characterizing reagents used in flotation, including selectivity and power (P.B. Kowalczuk, J. Drzymala, Selectivity and Power of Frothers in Copper Ore Flotation, Physicochem. Probl. Miner. Process. 53(1), 515-523(2017)). In recent years he spent some time working with his research group on principles of flotation both from the kinetic and thermodynamic points of view. The principle idea regarding kinetics was that the main kinetic parameter is the process rate, not kinetic constants, providing information on the local, for a given time, kinetics. The numerous kinetic constants are parameters characterizing kinetics globally, regardless of time of the process (T. Ratajczak, J. Drzymala, P.B. Kowalczuk, Local and Global Assessment of Flotation Kinetics, E3S Web Conf., 8 (2016) 01033, Mineral Engineering Conference MEC2016, Swieradow-Zdroj, Poland, September P.B. Kowalczuk and J. Drzymala (Eds.), 25-28 (2016); J. Drzymala, T. Ratajczak, B.P. Kowalczuk, Kinetic Separation Curves Based on Process Rate Considerations, Physicochem. Probl. Miner. Process, 53(2), 983-995(2017)).

Prof. Drzymala together with his co-workers published several papers on Kupferschiefer, that is copper- and carbon-bearing shale. This component of the Zechstein-origin copper ore, which is mined and processed in Poland, creates numerous technological difficulties. Due to these works the properties of the shale are now well established (for instance J. Drzymala, P. Karwowski, K. Borowski, P.M. Pazik, P.B. Kowalczuk, 2017. A trail to classify Legnica-Glogow Copper Basin shale on the basis of carbonates, clays, organic carbon and copper contents was offered in the paper: Lupek miedzionosny III, Kowalczuk, P.B., Drzymala, J. (eds), WGGG PWr, Wroclaw, $52-58$ (2017) (in Polish). The obtained results on shale are useful for improving technology of their processing and either considered or applied, including application of dextrin (J. Drzymala, J. Kapusniak, P. Tomasik, A method of Production of Copper Concentrates Rich in Chalcocite, Polish Patent PL 195693 B1, 2007)).

Worthwhile to mention are two additional accomplishments resulting from cooperation with others. One is a model of separation process (M. Brozek, J. Drzymala, Universal Delineation of Particle Separation Systems and Separation Results of Stratified Material, Separation Science and Technology, $44(8), 1657-1674,2009)$ and the second is proving, among others, that not all completely wetting liquids of solid surface can be used as the reference material in the Washburn approach to determination of contact angle (P.B. Kowalczuk, J. Drzymala, Surface Flotation of Particles on Liquids. Principles and Applications, Colloids and Surfaces A: Physicochemical and Engineering Aspects, 393 (2012), 81-85).

Przemyslaw B. Kowalczuk Norwegian University of Science and Technology, Department of Geoscience and Petroleum, S. P. Andersens veg 15a, 7031 Trondheim, Norway

\section{List of publications}

1. J. Drzymala, J. Serkies, On the Lechosos Opals and Chrysoprases in the Weathering Zone of Serpentinites from Szklary (Lower Silesia), Bull. Acad. Sci., des Science de la Terrie, XXI, No. 2, 111-117(1973) 
2. J. Lekki, J. Drzymala, W. Szeja, Determination of Applicability of Dipropylacetal as Frother. Part I: Investigation of Interactions at the Chalcocite-Aqueous Solution Interface, Cuprum, No.3, 29-33(1977), in Polish

3. J. Lekki, J. Laskowski, J. Szczypa, J. Drzymala, Physical-chemical Models in the Research of Floatability of Minerals, XII IMPC, Sao Paulo 1977, No.2, 304-324(1980)

4. J. Drzymala, J. Lekki, Point of zero charge of metal oxides and hydroxides, Prace Naukowe Instytutu Chemii Nieorganicznej i Metalurgii Pierwiastków Rzadkich Politechniki, Studia i Materialy Nr 16, 1-56(1979), in Polish

5. J. Drzymala, J. Lekki, A Comparison of Methods Used for Determination of Point of Zero Charge Using Copper (II) Oxide as an Example, Prace Naukowe Instytutu Chemii Nieorganicznej i Metalurgii Pierwiastków Rzadkich Politechniki, Studia i Materia ${ }^{3} y$, Nr 16, 57-74(1979), in Polish

6. J. Drzymala, J. Lekki, J. Laskowski, Surface Dissociation Constants for Solid Oxide-Aqueous Solution System, Colloid and Polymer Sci., 257, 768-772(1979)

7. J. Drzymala, Adsorption Isotherm of Potential Determining Ions at the Oxide-Aqueous Solution Interface, Polish Journal of Chemistry, 53, 1809-1820(1979)

8. J. Drzymala, Determination of Concentration of Hydroxyl and Metal Hydroxyl Groups on the Surface of Oxides Based on Crystallographic Lattice Parameters, Wiadomoœci Chemiczne, 33, 101-121(1979), in Polish

9. J. Drzymala, J. Laskowski, Electrokinetic Measurements in Mineral Processing, Fizykochemiczne Problemy Mineralurgii - Physicochemical Problems of Mineral Processing, 12, 35-45(1980)

10. J. Drzymala, D.W. Fuerstenau, Selective Flocculation of Hematite in the Hematite-Quartz-Ferric IonsPolyacrylic Acid System. Part I. Activation and Deactivation of Quartz, Inter. Min. Process. Journal, 8, 265277(1981)

11. J. Drzymala, J. Laskowski, Application of Chelating Agents in Flotation, Fizykochemiczne Problemy Mineralurgii, 13, 39-64(1981), in Polish

12. F. Letowski, S. Michalak, G. Sokalska, J. Drzymala, J. Mordalski, Utilization of Wastes from Acid Leaching of Copper Concentrates, Polish Temporary Patent No. 110494, 1982, in Polish.

13. J. Drzymala, A New Variant of Carrier Magnetic Separation in Relation to Known Methods of Upgrading, Fizykochemiczne Problemy Mineralurgii - Physicochemical Problems of Mineral Processing, 14, 55-58(1982)

14. M. Kielkowska, J. Lekki, J. Drzymala, Flotation of Germanium n and p with Potassium Ethyl Xanthate, Inter. Min. Process. Journal, 9, 145-156(1982)

15. J. Drzymala, A. Luszczkiewicz, P. Simiczyjew, Hercynite-Pleonaste from Ilmenite-Magnetite Rocks of Krzemianka (NE Poland). Miner. Polonica, 13(2), 33-40(1982)

16. J. Drzymala, A. Łuszczkiewicz, P. Simiczyjew, Flotation Study on Hercynite High-Hercynite Ilmenite Ore, Inter. Miner. Process. Journal 10, 289-296(1983)

17. A. Łuszczkiewicz, J. Lekki, J. Drzymala, Difficulties Encountered During Upgrading of Polish IlmeniteMagnetite Ore, Prace IMN, Gliwice, 3/4, 119-124(1983), in Polish

18. J. Drzymala, A. Luszczkiewicz, J. Lekki, Separation of Steel from Wastes Containing Steel, Abrasives and Oil Phase, Fizykochemiczne Problemy Mineralurgii - Physicochemical Problems of Mineral Processing, 16, 58(1984), in Polish

19. J. Drzymala, A. Luszczkiewicz, Microlaboratory Study on Magnetic, Gravity, and High-tension Separation of Hercynite and Pleonaste from Low Grade Ilmenite Concentrates, Inter. Miner. Process. Journal, 14, 233238(1985)

20. J. Drzymala, M.M. Kielkowska, Infrared Spectrophotometric Analysis of Acidified Aqueous Sodium Oleate Solutions, Spectrochimica Acta, 41A, No.7, 949-950(1985)

21. J. Drzymala, L. Krajczyk, Electron Microscopic Observation of Fine Polydispersed Emulsion, Colloids and Surfaces, 15, 249-253(1985)

22. J. Drzymala, Chemical Equilibria in the Oleic Acid-Water-NaCl System, J. Colloid Interface Sci., 108, 257263(1985)

23. J. Drzymala, Potentiometric Titration of Sodium Oleate in Dilute Aqueous Solution, J. Colloid Interface Sci., 107, 442-445(1985)

24. J. Drzymala, Hydrophobization of Solids in Aqueous Oleate Solutions, Fizykochemiczne Problemy Mineralurgii - Physicochemical Problems of Mineral Processing, 18, 63-84(1986), in Polish 
25. G.C.C. Yang, J. Drzymala, Aqua-oleophilicity and Aqua-oleophobicity of Solid Surfaces, Colloids and Surfaces, 17, 313-315(1986)

26. J. Drzymala, R. Markuszewski, T.D. Wheelock, Selective Oil Agglomeration of Graphite in the Presence of Pyrite, Coal Preparation, 3, 89-98(1986)

27. J. Drzymala, R. Markuszewski, T.D. Wheelock, Influence of Air on Oil Agglomeration of Carbonaceous Solids in Aqueous Suspension, Inter. Miner. Process. Journal, 18, 277-286(1986)

28. J. Drzymala, D.W. Fuerstenau, Adsorption of Polyacrylamide, Partially Hydrolyzed Polyacrylamide and Polyacrylic Acid on Ferric Oxide and Silica, Process Technol.Proc., (Flocculation in Biotechnology and Separation Science), 45-60 (1987)

29. J. Drzymala, An Estimation of the Surface Ionization Constant of Oleic Acid in Aqueous Sodium Chloride Solution, Colloid and Polymer Sci., 265, 613-618(1987)

30. J. Drzymala, J. Lekki, M.Kie ${ }^{3}$ kowska, A Study of the Germanium-Sodium Oleate Flotation System, Powder Technology, 52, No.3, 251-256(1987)

31. J. Drzymala, J. Lekki, Application of Flotometry for Characterizing Flotation in the Presence of Particles Aggregation, Minerals Engineering, 1(4), 327-336(1988)

32. J. Drzymala, R. Markuszewski, T.D.Wheelock, Agglomeration with Heptane of Coal and other Materials in Aqueous Suspensions, Minerals Engineering, 1(4), 351-358(1988).

33. J. Mager, J. Lekki, J. Drzymala, Correlation Between Transportation of Oleic Acid Droplets onto Germanium Surface and Floatability, Materials Science Forum, No.25-26, Chemistry of Interface, J. Czarnecki Ed., Trans. Tech. Pub., USA, 509-512(1988)

34. J. Drzymala, J. Lekki, Mechanical, Contactless, and Collector Flotation in the Hallimond Tube, J. Colloid Interface Sci., 130, 197-204(1989)

35. J. Drzymala, J. Lekki, Flotometry-Another Way of Characterizing Flotation, J. Colloid Interface Sci., 130, 205210(1989)

36. E. Mularczyk, J. Drzymala, Separation of Oleic Acid from Fatty Acid Impurities, Separation Science and Technology, 24(1), 151-155(1989)

37. J. Drzymala, Book review (Reagents in Mineral Technology), Coal Preparation, 7, 115-116(1989)

38. J. Drzymala, Chemistry of Oleic Acid-Water-NaCl System vs. pH at 25C. Surfactants in Solution, V7, K.L. Mittal Ed., Plenum Press, New York, 483-496(1990)

39. J. Lekki, J. Drzymala, Flotometric Analysis of Collectorless Flotation of Sulfide Materials, Colloids and Surfaces, 44, 179-190(1990)

40. J. Drzymala, Properties of Oleate Aqueous Solutions and Emulsions, Prace Naukowe Instytutu Chemii Nieorganicznej i Metalurgii Pierwiastków Rzadkich Politechniki Wroclawskiej, Nr 61, Seria Monografie, Nr 29, Wroclaw,1-89(1990), in Polish

41. J. Drzymala, T.D. Wheelock, Determining the Oil Agglomeration Characteristics of a Coal Suspension by Monitoring Turbidity Changes, 3rd International Conf. on Process. and Utiliz. of High-Sulfur Coals, Elsevier, Amsterdam, 289-300(1990)

42. J. Lekki, J. Drzymala, Flotometric Analysis of Agglomeration in Flotation Systems, Prace Naukowe Instytutu Chemii Nieorganicznej i Metalurgii Pierwiastków Rzadkich Politechniki Wroclawskiej, Nr 63, Seria Konferencje Nr 15, Wroclaw, 38-44(1990), in Polish

43. J. Drzymala, R. Markuszewski, T.D. Wheelock, Oil Agglomeration of Sulfurized Pyrite, Minerals Engineering, 4, (2),161-172(1991)

44. J. Lekki, J. Drzymala, Flotometric Investigation of Hydrophobic Sulfide-diethyl Dixantogen System, Colloids and Surfaces, 55, 271-27(1991)

45. A. Boteva, J. Drzymala, K. Kovatshev, Oil Agglomeration of Oxide Minerals with Collectors, Ann.Higher Institute of Mining and Geology, Sofia, 24, Part III, 289-299(1988), in Bulgarian

46. J. Drzymala, R. Markuszewski, T.D. Wheelock, Pyrite Suppression in Oil Agglomeration of Coal, 1991 Intern. Conf. on Coal Science Proc., Butterworth, London, 1005-1008(1991)

77. J. Drzymala, T.D. Wheelock, Coal Hydrophobicity and its Role in Filtration and Dewatering, Filtration and Separation, 351-354(1991)

47. J. Drzymala, T.D. Wheelock, Potential Pyrite Depressants for Use in Oil Agglomeration of Fine-size Coal, Coal Preparation, 10, 189-B 201(1992) 
48. J. Drzymala, J. Lekki, A Short Note on Isoelectric Point of Oleic Acid in Aqueous Emulsions, Prace Nukowe Instytutu Górnictwa Politechniki Wroclawskiej Nr 65, Studia i Materiały Nr 23, 43-B 48 (1992)

49. J. Drzymala, T. Chmielewski, Flotometry of Very Hydrophobic Materials in the Multibubble Hallimond Tube, Prace Naukowe Instytutu Górnictwa Politechniki Wroclawskiej Nr 65, Studia i Materialy Nr 23, 49-62(1992)

50. J. Drzymala, T. Chmielewski, K.L. Wolters, D.H. Birlingmair and T.D. Wheelock, Microflotation Measurements Based on Modified Hallimond Tube, Trans. IMM, Sec.C., 101, C17-C24(1992)

51. J. Drzymala, J. Lekki, A Contribution to Understanding Oleate Flotation of Minerals, IV International (Turkish) Mineral Processing Symposium Antalya, 213-225(1992)

52. J. Drzymala, A.S Zulmanowicz, A. Luszczkiewicz, T. Chmielewski, Collectorless Flotation of Sulfides from Lubiñ-Glogow Copper Region, XXV Krakowska Konferencja Naukowo-Techniczna Przerobki Kopalin, 133142(1993), in Polish

53. J. Drzymala, T.D. Wheelock, Organic Thiols as Pyrite Depressants in Oil Agglomeration of Coal, Coal Preparation, 13, 53-62(1993).

54. J. Drzymala, Effect of Contact Angle on the Maximum Size of Floating Particles in a Monobubble Hallimond Tube, Proc. IV Intern.Conf. Mineral Processing, Assiut, Egypt, 1994

55. J. Drzymala, T.D. Wheelock, Effect of Oxidation and Thioglycolic Acid on Separation of Coal Pyrite by Selective Oil Agglomeration, Coal Preparation, 14, 1-11(1994)

56. J. Drzymala, Hydrophobicity and Collectorless Flotation of Inorganic Materials, Advances in Colloid and Interface Sci., 50, 143-186(1994)

57. J. Drzymala, Characterization of Materials by Hallimond Tube Flotation. Part 1: Maximum Size of Entrained Particles, Int J Miner. Process., 42, 139-152(1994)

58. J. Drzymala, Characterization of Materials by Hallimond Tube Flotation. Part 2: Maximum Size of Floating Particles and Contact Angle, Int. J. Miner. Process., 42, 153-167(1994) and erratum 43, 1995, 135

59. J. Drzymala, Separation of Magnetite from Synthetic Mixtures with Quartz by Oil Agglomeration, Prace Naukowe Instytutu Górnictwa Politechniki Wroclawskiej 76, Studia i Materiały 24, 63-72 (1994)

60. J. Drzymala, Interaction of Particles during Oleate Flotation in a Mono-bubble Hallimond Tube, Minerals Engineering, 8(9), 1023-34, 1995

61. J. Drzymala, J. Bigosinski, Collectorless Flotation of Sulfides Occurring in the Fore-Sudetic Copper Minerals Deposit of SW Poland, Mineralogia Polonica, 26(1), 63-73, 1995

62. J. Drzymala, T.D. Wheelock, Air Agglomeration of Hydrophobic Particles, in: Processing of Hydrophobic Minerals and Fine Coal, J.S. Laskowski and G.W.Poling Editors, Canadian Institute of Mining, Metallurgy and Petroleum, Montreal, Canada, 1995

63. A. Luszczkiewicz, J. Drzymala, A. Grotowski, Problems of Separation of Copper and Lead Sulfides by Flotation, Rudy i Metale Niezelazne, 40(8), 315-318, 1995 (in Polish)

64. E. Mularczyk, J. Drzymala, Removal of Decomposition Products from Sodium Oleate, Industrialand Engineering Chemistry Research, 35, 788-791. 1996

65. J. Drzymala, Difficulties in Separating Copper and Lead Sulfides by Xanthate Flotation: Negative Role of Contact of Particles in the Presence of Depressants, in: Changing Scopes in Mineral Processing, Kemal, Arslan, Akar and Canbazoglu (eds), Balkema, Rotterdam, 225-228, 1996

66. J. Drzymala, T.D. Wheelock, Preliminary Characterisation of a Gas-Promoted Oil Agglomeration Process, Thirteenth Annual International Pittsburgh Coal Conference, Proceeding "Coal-Energy and the Environment, Shiao-Huang Chiang (Ed.), University of Pittsburgh, V. 2, 898-903, 1996

67. J. Bigosinski, J. Drzymala, Microscopic Determination of Content of Chalcocite in Mixtures with Galena after Thermal Modification of Their Surfaces, Zeszyty Naukowe Politechniki Śląskiej (Poland), Seria Górnictwo, Z.231, 37-45, 1996

68. J. Drzymala, The Importance of Contact Angle Equal to 90 Degrees in Interfacial Processes, Proc. International Conference on Analysis and Utilization of Oily Wastes, AUZO'96, Gdansk, Poland, 393-396, 1996

69. J. Drzymala, J. Lekki, Diagrams Containing Lines of Concentration of Bulk Species and Surface Sites for Selected Oxide-Water Systems, Prace Naukowe Instytutu Górnictwa Politechniki Wroclawskiej (Poland), 81, Studia i Materiały Nr 26, 61-69, 1996

70. J. Drzymala, T.D. Wheelock, Air Promoted Oil Agglomeration of Moderately Hydrophobic Coals. 2. Effect of Air Dosage in a Model Mixing System, Coal Preparation, 18, 37-52, 1997 
78. J. Bogosinski, J. Drzymala, Barriers of Upgrading in Flotation Systems Containing Chalcocite and Galena, Gospodarka Surowcami Mineralnymi, 13, 9-20 (1997), in Polish

79. J. Drzymala et al., Thomas Alva Edison and His Contribution to Development of Mineral Processing, Prace Naukowe Instytutu Górnictwa Politechniki Wroclawskiej 85, Studia i Materialy 27, 13-20 (1998), in Polish

80. J. Pierzak, J. Drzymala, Allotropic Forms of Elemental Carbon, Prace Naukowe Instytutu Górnictwa Politechniki Wroclawskiej 85, Studia i Materialy 27, 63-78 (1998), in Polish

81. J. Drzymala, Characterization of Materials by Hallimond Tube Flotation. Part 3: Maximum Size of Floating and Interacting Particles, Int. J. Miner. Process., 55, 203-218(1999)

82. J. Drzymala, Entrainment of Particles with Density Between 1.01 and $1.10 \mathrm{~g} / \mathrm{cm}^{3}$ in a Monobubble Hallimond Tube, Minerals Engineering, 12 (3), 329-331 (1999)

83. J. Drzymala, Flotometric Hydrophilicity of Coal Particles, Mining Science and Technology, H. Xie, T.S. Golosinski (editors), Proc.'99 Int. Symp. Mining and Technology, Beijing, China, Balkema, Rotterdam, 533537(1999)

84. J. Drzymala, Z. Sadowski, L. Holysz E. Chibowski, Ice/Water Interface, Zeta Potential, Point of Zero Charge, and Hydrophobicity, J.Colloid Interface Sci., 220, 229-234 (1999)

85. J. Drzymala, V. Vigdergauz, Work and Force of Bubble-Particle Detachment as a Measure of Contact Angle in Flotation Systems, Scientific Papers of the Institute of Mining Engineering, 87, „Studia i Materialy" Series, 28, 3-11(2000)

86. J. Drzymala, J. Kapusniak, P. Tomasik, Amino Acid Dextrins as Selective Depressants in Flotation of Chalcocite and Galena, Physicochemical Problems of Mineral Processing (Fizykochemiczne Problemy Mineralurgii), 34, 101-110(2000)

87. J. Drzymala, J. Kapusniak, P. Tomasik, A Method of Production of Copper Concentrates Rich in Chalkozyn, Polish Patent Application, 2000

88. K. Pradel, J. Drzymala, Determination of Flotational Hydrophobicity of Minerals Using Probabilistic Models of Flotation, Scientific Papers of the Institute of Mining Engineering 88, Conferences 25, 2000, in Polish

89. J. Drzymala, V. Vigdergauz, 2000. Particle-Bubble Water Contact Angle Based on Flotation in a Hallimond Tube, 13 IMPC, Rome, Elsevier, B8a-79 - B8a-86

90. J. Drzymala, Foundations of Mineral Processing (Podstawy mineralurgii), Oficyna Wydawnicza Politechniki Wroclawskiej, 1 - 478, 2001, in Polish

91. J. Drzymala, Generating Upgrading Curves Used for Characterization of Separation Processes - Generowanie krzywych wzbogacania stosowanych do charateryzowania procesów separacji, Inżynieria Mineralna - Journal of the Polish Mineral Engineering Society, II, 2(4), 35-40, 2001

92. Z. Konopacka, J. Drzymala, Generating Classification Curves Applied to Delineation of Separation Processes, Scientific Papers of the Institute of Mining Engineering 96, Conferences 32, 25-33, 2002, in Polish

93. 87. T.Ratajczak, J.Drzymala, Evolution of Hypotheses of Mechanism Salt Flotation, Scientific Papers of the Institute of Mining Engineering 96, Conferences 32, 33-43, 2002, in Polish

94. J. Drzymala, Study of the Ice-Water Interface, Encyclopedia of Surface and Colloid Science, 4892-4898, 2002, Arthur T. Hubbard (editor), Marcel Dekker, New York

95. J. Drzymala, A. Kozłowski, Wpływ czasu starzenia przemysłowego koncentratu miedzi z KGHM Polska MiedźS.A. na selektywność usuwania z niego minerałów ołowiu na drodze flotacji, Prace Naukowe Instytutu Górnictwa Politechniki Wroclawskiej 101, Konferencje 35, 51-57, 2002

96. J. Drzymala, P. Tomasik, B. Sychowska, M. Sikora, Dextrins as Selective Flotation Depressants for Sulfide Minerals, Fizykochemiczne Problemy Mineralurgii - Physicochemical Problems of Mineral Processing, 36, 273-278, 2002

97. J. Drzymala, Creation and catogerization of separation parameters - Tworzenie i kategoryzacja parametrów separacji, Inżynieria Mineralna - Journal of the Polish Mineral Engineering Society, III, 1(5), 11-19, 2002

98. J. Drzymala, A. Kozłowski, Wpływ czasu przechowywania rozdrobnionej rudy miedzi z Lubina na jej ksantogenianową flotację, Prace Naukowe Instytutu Górnictwa Politechniki Wroclawskiej 102, Studia i Materiały 29, 39-44 (2002)

99. J. Drzymala, J. Kucal, A. Kozłowski, Flotacja rudy miedzi za pomocą kolektorów stosowanych jako promotory flotacji węgla, Prace Naukowe Instytutu Górnictwa Politechniki Wroclawskiej 102, Studia i Materiały 29, 45 53,2002 
100. J. Drzymala, J. Kapuśniak, P. Tomasik, Removal of Lead Minerals from Copper Industrial Flotation Concentrates by Xanthate Flotation in the Presence of Dextrin, Int. J. Miner. Process., 70, 147-155, 2003

101. J. Drzymala, E. Mielczarski, J. Duval, J. Mielczarski, Hydrophobicity and Flotation of Quartz and Feldspar in the Presence of Monoalkyl Polyethylene Glycol Ethers, Proc. XXII Int.Min. Proc. Congr., Cape Town, South Africa, L. Lorenzen, D.J. Bradshow Eds., Document Transformation Technologies, 1094-1101, 2003

102. A.M. Hussin Ahmed, J. Drzymala, Creation, Properties and Possible Utilization of Microemulsions in Mineral Processing, Prace Naukowe Instytutu Górnictwa Politechniki Wroclawskiej 103, Konferencje 36, 273-283, 2003

103. W. Apostoluk, J. Drzymala, An Improved Estimation of Water-Organic Liquid Interfacial Tension Based on Linear Solvation Energy Relationship Approach, J. Colloid Interface Sci., 262, 483-488, 2003

104. T. Ratajczak, J. Drzymala, Flotacja solna, Oficyna Wydawnicza Politechniki Wroclawskiej, 2003

105. J. Drzymala, Sorting as a Procedure of Evaluating and Comparing Separation Results, Physicochemical Problems of Mineral Processing - Fizykochemiczne Problemy Mineralurgii, 37, 19-26, 2003

106. J. Drzymala, E. Hrycyna, Entrainment of Particles in the Mechanobr Laboratory Flotation Machine, Prace Naukowe Instytutu Górnictwa Politechniki Wroclawskiej 106, Studia i materiały 30, 21-29, 2004

107. J. Drzymala, A. Kozłowski, Wpływ masy molowej polisacharydow zawierających mery D-glukozowe z wiązaniami glikozydowymi na selektywność odołowiania koncentratu miedzi, Prace Naukowe Instytutu Górnictwa Politechniki Wroclawskiej 106, Studia i materiały 30, 31-43, 2004

108. H.A.M. Ahmed, J. Drzymala, Effect of Flotation Procedure and Composition of Reagents on Yield of a Difficult-to-Float Coal, Physicochemical Problems of Mineral Processing, 38, 53-63, 2004

109. J. Drzymala, Evaluation and Comparison of Separation Performance for Varying Feed Composition and Scattered Separation Results, Int. J. Miner. Process., 75, 189-196, 2005

110. J. Drzymala, H.A.M. Ahmed, Mathematical Equations for Approximation of Separation Results Using the Fuerstenau Upgrading Curves, Int. J. Miner. Process., 76, 55-65, 2005

111. J. Drzymala, T.D. Wheelock, Oil agglomeration of Solid Particles Suspended in Water by Means of Organic Liquids, Proc. Conf. Oils and Enviroment, AUZO 2005, J.Hupka, R. Aranowski eds., Gdansk University of Technology and Pomcert, 98-105

112. H.A.M. Ahmed, J. Drzymala, Two-Dimensional Fractal Linearization of Distribution Curves, Physicochemical Problems of Mineral Processing, 39, 129-139, 2005

113. J. Drzymala, J.T. Gorke, T.D. Wheelock. A flotation Collector for the Separation of Unburned Carbon from Fly Ash, Coal Preparation, 25, 67-80, 2005

114. H. A.M. Ahmed, J. Drzymala, Direct Material-Reagent Contact Approach for Upgrading Ddifficult-to-Float Coals, Prace Naukowe Instytutu Górnictwa Politechniki Wroclawskiej 110, Konferencje 42, 355-364, 2005

115. J. Drzymala, Derivation of a Separation Curve Based on Thermodynamic Considerations and Variation of Splitting Force, Prace Naukowe Instytutu Górnictwa Politechniki Wroclawskiej 31, Studia i materiały 113, 3545, 2005

116. 110. J. Drzymala, Structure of Separation Processes and Ways of Analysis of Separation Results, Inżynieria Mineralna - Journal of the Polish Mineral Engineering Society, VI, 2(15), 3-11, 2005

117. N. Kallay, J. Drzymala, A. Cop, Electrical Charge at Ice-Aqueous Electrolyte Interface, Encyclopedia of Surface and Colloid Science, 2nd ed., P. Somasundaran editor, 1899 - 1907, 2006

118. J. Drzymala, Atlas of Upgrading Curves Used in Separation and Mineral Science and Technology, Physicochemical Problems of Mineral Processing, 40, 19-29, 2006

119. D. Szyszka, J. Drzymala, J. Łuczyński, K.A. Wilk, J. Patkowski, Concentration of $\alpha$-Terpineol and (2dodecanoyloxyethyl)trimethy-lammonium bromide required for Prevention of Air Bubble Coalescence in Aqueous Solutions, Physicochemical Problems of Mineral Processing, 40, 53-59, 2006

120. D.V. Trong, J. Hupka, J. Drzymala, Impact of Roughness on Hydrophobicity of Particles Measured by the Washburn Method, Physicochemical Problems of Mineral Processing, 40, 45-52, 2006

121. A. Luszczkiewicz, Ż. Konopacka, J. Drzymala, Flotacja czarnych łupków z Lubińskich rud miedzi, (Flotation of black shale from Lubin copper ore), BIOPROCOP '06, Proceedings of conference on Perspecitives for appying bioleaching technology to process shale-baering copper ores, Lubin, 19 June 2006, Poland, 29-47, 2006

122. J. Drzymala, E. Mielczarski, J. A. Mielczarski, Adsorption and Flotation of Hydrophilic Materials in the Presence of Hydrocarbon Polyethylene Glycol Ethers, Colloids and Surfaces, A., Physicochem. Eng. Aspects, 308, 2007, 111-117 
123. J. Drzymala, D. Tyson, T.D. Wheelock, Presentation of Particle Beneficiation Test Results on an Equal Basis when Yield and Recovery are Involved, Minerals and Metallurgical Processing, 24 (3), 2007, 145-151

124. J. Zawala, J. Drzymala, K. Malysa, Natural Hydrophobicity and Flotation of Fluorite, Physicochemical Problems of Mineral Processing, 41, 5-11, 2007

125. J. Drzymala, Atlas of Upgrading Curves Used in Separation and Mineral Science and Technology (Part II), Physicochemical Problems of Mineral Processing, 41, 27-35, 2007

126. J. Grodzka, J. Drzymala, A. Pomianowski, Surface Material Constants, in: SURUZ 2007, Surfactants and dispersed systems in theory and practice, International Scientific Conference, Ksiaz, Poland, K.A.Wilk (editor). Palmapress, Wroclaw, 2007, 505-508

127. J. Drzymala, J. Kapusniak, P. Tomasik, A method of Production of Copper Concentrates Rich in Chalcocite, Polish Patent PL 195693 B1, 2007

128. J. Drzymala, Mineral Processing. Foundations of Theory and Practice of Minerallurgy, Oficyna Wyd. PWr., Wroclaw, 2007, 507 pages, http://www.dbc.wroc.pl/dlibra/docmetadata?id=2070\&from=publication

129. J. Drzymala, Atlas of Upgrading Curves Used in Separation and in Mineral Science and Technology, Physicochemical Problems of Mineral Processing, Part 3., 42 (2008) 75-84

130. J. Zawała, J. Drzymala, K. Malysa, An Investigation into the Mechanism of the Three-Phase Contact Formation at Fluorite Surface by Colliding Bubble, International Journal of Mineral Processing, 88(2008) 72-79

131. J. Grodzka, J. Drzymala, A. Pomianowski, Interfacial Material Constants for Systems of Fine Sizes, Physicochemical Problems of Mineral Processing, 42 (2008) 237-250

132. D. Szyszka, E. Glapiak, J. Drzymala, Entrainment-Flotation Activity of Quartz in the Presence of Selected Frothers, Physicochemical Problems of Mineral Processing, 42 (2008) 85-90

133. D. Szyszka, J. Drzymala, P. Resiak, E. Mielczarski, J. Mielczarski, Entrainment of Quartz in Flotation Tests with Frothers, XXIV IMPC, Beijing, China, 2008, v.1.1068-1073

134. B. Grabowski, J. Drzymala, 2008. Graphite Flotation in the Presence of Sodium Acetate, Annales Universitatis Mariae Curie-Sklodowksa - Lublin - Polonia, Vol. LXII, 6, Section AA, 58-72

135. J. Drzymala, J.Grodzka, A. Pomianowski, Rapeseed Oil as a Collector in Flotation of Sulfide Copper Ore, in: Oils and Fuels for Sustainable Development, Chapter 26, 201-204, Gdańsk, 2008

136. 130. J. Drzymala, J.Grodzka, A.Pomianowski, Fizykochemiczna charakterystyka układów rozdrobnionych w mineralurgii i biologii, Wydawnictwo Politechniki Wroclawskiej, 1-131, 2008

137. W. Sawiński, T.Koźlecki, A.Sokołowski, I.Polowczyk, J.Drzymala, 2008. Flotation of Bituminous Coal Using Hydroxyazobenzene Derivatives. Proc. 11th International Mineral Processing Symposium, Belek-Antalya, Turkey, 21-23 October 2008, Gulhan Ozbayoglu Ed., Turkish Mining Development Foundation, 701-706

138. M. Brozek, J. Drzymala, Universal Delineation of Particle Separation Systems and Separation Results of Stratified Material, Separation Science and Technology, 44(8), 1657 - 1674, 2009

139. J. Drzymala, Principles of Mineral Processing, 2nd edition, 2009, http://www.dbc.wroc. pl/dlibra/docmetadata?id=3111\&from=\&dirids=1\&ver_id=147180\&lp=1\&QI=306F0F122D3FD8E6D66C7B1 2481141C2-1 (in Polish)

140. J. Drzymala, D. Foszcz, A. Luszczkiewicz, 2009. Evaluation of Industrial Enrichment of Ores, Cuprum 1-2(5051), 75-90 (in Polish)

141. J. Drzymala, A. Luszczkiewicz, D. Foszcz, 2010, Application of Upgrading Curves for Evaluation of Past, Present and Future Performance of a Separation Plant, Mineral Processing and Extractive Metallurgy Review, 31(3) 165-175

142. Z. Konopacka, J. Drzymala, 2010, Types of Particles Recovery-Water Recovery Entrainment Plots Useful in Flotation Research, Adsorption, 16 (4), 313-320

143. J. Drzymala, P.B. Kowalczuk, 2010, Problems with Statistical Evaluation of Separation Results, Proc. XIIth International Mineral Processing Symposium, O.Y. Gulsoy, S.L. Ergun, N.M. Can, I.B. Celik editors, Min. Eng. Dep, Hacettepe Univ., Ankara, pp. 1191-1202

144. E. Szymkowiak, J. Drzymala, 2010. Problem with Choosing an Upgrading Curve for Evaluation of Flotation Results (in Polish), Prace Naukowe Instytutu Górnictwa, 131 (38), 47-56

145. J. Drzymala, M. Mikołajczyk, D. Piwowar, B. Polak, H. Drzymala, J. Ragiel, M. Drzymala-Tronina, 2010. Johann Wolfgang von Goethe and His Input into Development of Mining and Geology (in Polish), Prace Naukowe Instytutu Górnictwa, 131 (38), 35-46 
146. M. Watanabe, P.B. Kowalczuk, J. Drzymala, 2011. Analytical Solution of Equation Relating Maximum Size of Foating Particle and its Hydrophobicity, Physicochemical Problems of Mineral Processing, 46, 13-20

147. P.B.K owalczuk, J. Drzymala, Contact Angle of Bubble with Immersed-in-water Particle of Different Materials, Industrial and Engineering Chemistry Research, 2011, 50(7), 4207-4211

148. P.B. Kowalczuk, O. Sahbaz, J. Drzymala, Maximum Size of Floating Particles in Different Flotation Cells, Minerals Engineering, 2011, 24(8), 766-771

149. D. Foszcz, J. Drzymala, Differentiation of Organic Carbon, Copper and Other Metals Contents by Segregating Flotation of Final Polish Industrial Copper Concentrates in the Presence of Dextrin, Physicochemical Problem of Mineral Processing, 47(2011), 17-26

150. M. Duchnowska, J. Drzymala, Transformation of Equation $y=a(100-x) /(a-x)$ for Approximation of Separation Results Plotted as Fuerstenau's Upgrading Curve for Application in Other Upgrading Curves, Physicochemical Problem of Mineral Processing, 47(2011), 123-130

151. J. Drzymala, P.B. Kowalczuk, A proposition for Symbolism of Non-ideal Separations Followed by Analytical Separations used for Evaluation of Separation Efficiency, Mineral Processing and Extractive Metallurgy Review, 2011, 32, 278-288

152. M. Duchnowska, J. Drzymala, Wpływ jakości nadawy na jakaść produktów wzbogacania ocenianych za pomoca wykresu Fuerstenaua dla przypadku symetrycznej krzywej separacji, Gospodarka Surowcami Mineralnymi, 37(2), 2011, 33-41

153. J. Drzymala, A. Luszczkiewicz, Zalety krzywej uzysk-uzysk (Fuerstenaua) do technolo-gicznej analizy i oceny wzbogacania surowców, Przeglad Gorniczy, 2011, 7/8, 122-128

154. J. Drzymala, Dekstryny jako reagent flotacyjny segregujący polskie przemysłowe koncentraty miedziowe na dwa produkty o zróżnicowanej zawartości węgla organicznego, Przeglad Gorniczy, 2011, 7/8, 104-107

155. P.B. Kowalczuk, J. Drzymala, Surface Flotation of Particles on Liquids. Principles and Applications, Colloids and Surfaces A: Physicochemical and Engineering Aspects, 393 (2012), 81-85

156. P. Kowalczuk, J. Drzymala, Letter to Editor on Detachment of Coarse Particles from Oscillating Bubbles -The effect of Particle Contact Angle and Medium Viscosity" by D. Xu, I. Ametov and S.R. Grano (Int. J. Miner. Process. 101(1-4), 50-57), International Journals of Mineral Processing, 104-105(2012) 80-81

157. M. Duchnowska, J. Drzymala, 2012, Self-similarity of Upgrading Parameters Used for Evaluation of Separation Results, Int. J. Mineral. Processing, 106-109, 50-57

158. J. Drzymala, J. Lyklema, Surface Tension of Aqueous Electrolyte Solutions. Thermodynamics, J. Phys Chem. A., 116(25), 6465-72, 2012

159. H.A.H. Ahmed, J. Drzymala, Upgrading Difficult-to-float Coal Using Microemulsion, Minerals and Metalurgical Processing, 29(2), 88-96, 2012

160. J. Drzymala, P.B. Kowalczuk, D. Foszcz, A. Muszer, T. Henc, A. Luszczkiewicz, Analysis of Separation Results by Means of the Grade-Recovery Halbich Upgrading Curve, IMPC, New Delhi, 2012, paper 127

161. T. Ratajczak, J. Drzymala, Excess Interfacial Energy Change of Solid/Aqueous Salt Solution System with Increasing Salt Concentration at a Constant Charge-Determining Ion Activity Based on the Gibbs Equation and Ionic Components of Charge, Central European Journal of Chemistry, 10(6), 2012, 1927-1932

162. M.S. Aljuhani, H.A.M. Ahmed, J. Drzymala, Polish Patent Application, P401490, 2012, A Method of Upgradng of Phosphate Raw Materials

163. A. Bakalarz, J. Drzymala, 2013, Interrelation of the Fuerstenau Upgrading Curve Parameters with Kinetics of Separation, Physicochemical Problem of Mineral Processing, 49(2), 443-451

164. J. Drzymala, P.B. Kowalczuk, M. Oteng-Peprah, D. Foszcz, A. Muszer, T. Henc, A. Luszczkiewicz, 2013, Application of the Grade-Recovery Curve in the Batch Flotation of Polish Copper Ore, Minerals Eng., 49, 1723

165. H.A.M. Ahmed, M.S. Aljuhani, J. Drzymala, 2013. Flotation After direct Contact of Flotation Reagents with Particles. Part I. Model Investigations, Physicochemical Problem of Mineral Processing, 49(2), 713-723

166. T. Chmielewski, J. Drzymala, A. Łuszczkiewicz, A. Trochimczuk, Z. Adamski. J. Wódka, P.B. Kowalczuk, K. Ochromowicz, K. Gibas, K. Borowski, A. Muszer, B. Woźniak, 2013. Sposób hydrometalurgicznego przerobu surowców polimetalicznych, Patent application P405901

167. H.A.M. Ahmed, M.S. Aljuhani, J. Drzymala, 2014, Flotation After a Direct Contact of Flotation Reagents with Particles. Part II. Phosphate Ore, Materials Testing for Mining, 56(2014), p.1-5 
168. J. Drzymala, D.W. Fuerstenau, 2014. Selective Flocculation of Hematite in Quartz -Hematite-Ferric ionPolyacrylic Acid System. Part 2. Effect of Grinding and a Hydrofluoric Treatment on Selectivity of Flocculation, 2014, Int. J. Min. Proc., 129, 1-5

169. P. B. Kowalczuk, B. Buluc, O. Sahbaz, J. Drzymala, 2014. In Search of an Efficient Frother for Pre-flotation of Carbonaceous Shale from the Kupferschiefer Stratiform Copper Ore, Physicochemical Problems of Mineral Processing, 50(2), 835-840

170. L. Lazarek, A. Antonczak, M. Wojcik, J. Drzymala, K. Abramski, 2014. Evaluation of the Laser-Induced Breakdown Spectroscopy Technique for Determination of the Chemical Composition of Copper Concentrates, Spectrochimica Acta. Part B, Atomic Spectroscopy, 1-9

171. J. Drzymala, 2013. Separation in mineral processing - delineation, analysis and evaluation, in: Separation science - theory and practice, Proceedings of the 2nd International Conference on Methods and Materials for Separation Processes, 9-13 June 2013, Świeradów Zdrój, Poland, Anna Jakubiak-Marcinkowska, Andrzej W. Trochimczuk eds, Wroclaw, Oficyna Wydawnicza Politechniki Wroclawskiej, 26-29

172. M. Peng, T. Ratajczak, J. Drzymala, 2014, Zeta potential of Polish Copper-Bearring Shale in the Absence and Presence of Flotation Frothers, Mining Science, 21, 57-63

173. K. Cependa, J. Drzymala, M.P. Lewicka, Gęstość łupka miedziowego, in: Łupek miedzionośny, Drzymala J., Kowalczuk P.B. (red.), WGGG PWr, Wroclaw, 2014, 19-21

174. M. Stodulski, J. Drzymala, Densymetria łupka miedziowego, in: Łupek miedzionośny, Drzymala J., Kowalczuk P.B. (red.), WGGG PWr, Wroclaw, 2014, 23-27

175. K.B. Kruszakin, J. Drzymala, Koagulacja łupka miedziowego, in: Łupek miedzionośny, Drzymala J., Kowalczuk P.B. (red.), WGGG PWr, Wroclaw, 2014,29-32

176. P. Róg, J. Drzymala, Roztwarzanie łupka miedzionośnego w kwasach nieorganicznych, in: Łupek miedzionośny, Drzymala J., Kowalczuk P.B. (red.), WGGG PWr, Wroclaw, 2014, 39-42

177. W. Karczmarz, J. Drzymala, Rozpad łupka miedziowego pod wpływem cieczy organicznych, in: Łupek miedzionośny, Drzymala J., Kowalczuk P.B. (red.), WGGG PWr, Wroclaw, 2014, $43-46$

178. K. Kącka, J. Drzymala, Odziaływanie łupka miedzionośnego z cieczą jonową, in: Łupek miedzionośny, Drzymala J., Kowalczuk P.B. (red.), WGGG PWr, Wroclaw, 2014, 47-49

179. M. Peng, J. Drzymala, Dzeta potencjał łupka miedziowego w wodzie oraz w wodnych roztworach spieniaczy flotacyjnych, in: Łupek miedzionośny, Drzymala J., Kowalczuk P.B. (red.), WGGG PWr, Wroclaw, 2014, 5760

180. M. Peng, J. Drzymala, Porównywanie uzysków łupka miedzionośnego flotacyjnie separowanego z mieszaniny modelowej z kwarcem w obecności spieniaczy, in: Łupek miedzionośny, Drzymala, J., Kowalczuk, P.B. (red.), WGGG PWr, Wroclaw, 2014, 71-75

181. J. Drzymala, Flotometryczna hydrofobowość łupka miedzionośnego, in: Łupek miedzionośny, Drzymala J., Kowalczuk P.B. (red.), WGGG PWr, Wroclaw, 2014, 77-82

182. J. Cichański, J. Drzymala, Flotacja łupka miedziowego w obecności gamma-walerolaktonu jako spieniacza, in: Łupek miedzionośny, Drzymala J., Kowalczuk P.B. (red.), WGGG PWr, Wroclaw, 2014, 99-102

183. P.B. Kowalczuk, D. Mroczko, J. Drzymala, 2015, Influence of Frother Type and Dose on Collectorless Flotation of Copper-Bearing Shale in a Flotation Column, Physicochem. Probl. Miner. Process. 51(2), 547-558

184. A. Bakalarz, M. Duchnowska, A. Konieczny, E. Kasinska-Pilut, W. Pawlos, R. Kaleta, P.B. Kowalczuk, J. Drzymala, A. Łuszczkiewicz, 2015, Kinetics of Laboratory Flotation of Copper Ore from Polkowice Division of Concentrators After Milling in the Presence of Grinding Media with Different Chemical Composition, CUPRUM-Czasopismo Naukowo-Techniczne Górnictwa Rud 2(75), 55-70 (in Polish)

185. A. Konieczny, M. Duchnowska, R. Kaleta, W. Pawlos, P.B. Kowalczuk, M. Krzeminska, A. Bakalarz, E. Kasinska-Pilut, J. Predki, A. Luszczkiewicz, J. Drzymala, 2015, Analysis of Results of Organic Carbon Separation From a Copper Ore by Means of Flotation with Frothers. XIth International Conference on NonFerrous Ore Processing ICNOP'2015, Trzebieszowice, 27-29.05.2015, pp. 147-155 (in Polish)

186. M. Lipniarski, T. Ratajczak J. Drzymala, 2015, Weryfikacja hipotez o roli soli we flotacji na przykładzie węgla

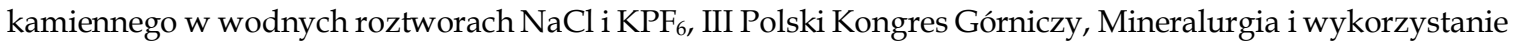
surowców mineralnych, Drzymala J., Kowalczuk P.B. (red.), 14-16 września 2015, Wroclaw, WGGG PWr, 3539

187. P.B. Kowalczuk, J. Drzymala, 2016, Some Remarks on Attachment of a Gas Bubble to Another Phase Both Immersed in Water. Physicochem. Probl. Miner. Process. 52(1), 147-154 
188. P.B. Kowalczuk, J. Drzymala, 2016, Physical Meaning of the Sauter Mean Diameter of Spherical Particulate Matter, Part. Sci. Technol., 34(6), 645-647

189. M.J. Janicki, J. Drzymala, P.B. Kowalczuk, 2016, Structure and Surface Energy of Both Fluorite Halves After Cleaving Along Selected Crystallographic Planes., Physicochem. Probl. Miner. Process. 52(1), 451-458

190. P.B. Kowalczuk, J. Zawala, D. Kosior, J. Drzymala, K. Malysa, 2016, Three-Phase Contact Formation and Flotation of Highly Hydrophobic Polytetrafluoroethylene in the Presence of Increased Dose of Frothers, Ind. Eng. Chem. Res. 2016, 55 (3), 839-843

191. P.B. Kowalczuk, J. Zawala, J. Drzymala, K. Malysa, 2016. Influence of Hexylamine on Kinetics of Flotation and Bubble Attachment to the Quartz Surface, Separation Science and Technology, 51 (15-16), 2681-2690

192. M. Stodulski, J. Drzymala, Flotation of Copper Bearing Carbonaceous Shale in the Presence of Amine Type Frothers, Annales Universitatis Curie-Skłodowska, vol. LXXI, 1, Sec. AA, 2016, 69-78

193. M. Duchnowska, A. Luszczkiewicz J. Drzymala, 2014, Comparison of Effectiveness of Working in Parallel Streams Industrial Flotation Machines. XVII International Mineral Processing Congress, IMPC 2014. Vol. 1, Santiago, Chile, October 20-24, Juan Yianatos ed., Santiago, Chile: IMPC, 1-10

194. Y. Katmer, E. Tünbel, O. Sahbaz, J. Drzymala, Wstępne badania aglomeracji olejowej łupka miedzionośnego, in: Łupek miedzionośny II, Kowalczuk P.B., Drzymala J. (red.), WGGG PWr, Wroclaw, 2016, 64-66

195. J.A. Kuriata, J. Drzymala, Aglomeracja olejowa łupka miedzionośnego i próba jego aglomeracji sferycznej w obecności kwasu oleinowego zmieszanego z heptanem, in: Łupek miedzionośny II, Kowalczuk P.B., Drzymala J. (red.), WGGG PWr, Wroclaw, 2016, 67-73

196. A. Tyrlicz, J. Drzymala, Próba wzbogacenia łupka miedziowego za pomocą separatora elektrycznego, in: Łupek miedzionośny II, Kowalczuk P.B., Drzymala J. (red.), WGGG PWr, Wroclaw, 2016, 91-96

197. T. Grzeszczuk, J. Drzymala, Wpływ prażenia na zmianę składu ziarnowego łupka miedzionośnego, in: Łupek miedzionośny II, Kowalczuk P.B., Drzymala J. (red.), WGGG PWr, Wroclaw, 2016, 105-108

198. D. Mizera, J. Drzymala, Odziaływanie łupka miedzionośnego z kwasem fluorowodorowym, in: Łupek miedzionośny II, Kowalczuk P.B., Drzymala J. (red.), WGGG PWr, Wroclaw, 2016, 109-112

199. P.M. Pązik, J. Drzymala, PB. Kowalczuk, Flotacja łupka miedzionośnego w zależności od pH w wodzie technologicznej, in: Łupek miedzionośny II, Kowalczuk P.B., Drzymala J. (red.), WGGG PWr, Wroclaw, 2016, 118-122

200. M. Kiędracha, J. Drzymala, Flotacja łupka miedzionośnego w zależności od pH regulowanego nietypowymi reagentami, in: Łupek miedzionośny II, Kowalczuk P.B., Drzymala J. (red.), WGGG PWr, Wroclaw, 2016, 123126

201. M. Redlicki, J. Drzymala, Wpływ temperatury na flotację łupka miedzionośnego, in: Łupek miedzionośny II, Kowalczuk P.B., Drzymala J. (red.), WGGG PWr, Wroclaw, 2016, 132-135

202. R. Więcewicz, J. Drzymala, Flotacja łupka miedzionośnego w obecności metyloizobutylo-karbinolu jako spieniacza i olejów jako zbieraczy, in: Łupek miedzionośny II, Kowalczuk P.B., Drzymala J. (red.), WGGG PWr, Wroclaw, 2016, 161-165

203. E.J. Hammoudeh, J. Drzymala, Flotacja łupka miedzionośnego spieniaczem i ksantogenianami, in: Łupek miedzionośny II, Kowalczuk P.B., Drzymala J. (red.), WGGG PWr, Wroclaw, 2016, 166-169

204. J. Lasia, M. Łakota, J. Drzymala, Flotacja łupka miedzionośnego za pomocą spieniaczy i ich mieszanin, in: Łupek miedzionośny II, Kowalczuk P.B., Drzymala J. (red.), WGGG PWr, Wroclaw, 2016, 170-174

205. P.M. Pązik, J. Drzymala, P.B. Kowalczuk, Wpływ mieszanych spieniaczy na flotację łupka miedzionośnego, in: Łupek miedzionośny II, Kowalczuk P.B., Drzymala J. (red.), WGGG PWr, Wroclaw, 2016, 175-179

206. A. Skowrońska, J. Drzymala, Flotacja łupka miedzionośnego w obecności elektrolitów podwyższających i obniżających napięcie powierzchniowe wody, in: Łupek miedzionośny II, Kowalczuk P.B., Drzymala J. (red.), WGGG PWr, Wroclaw, 2016, 190-183

207. E. Tünbel, Y. Katmer, J. Drzymala, Flotacja łupka miedziowego w obecności dodecylofenolu, in: Łupek miedzionośny II, Kowalczuk P.B., Drzymala J. (red.), WGGG PWr, Wroclaw, 2016, 192-194

208. P. Merta, J. Drzymala, Wpływ chlorku sodu i octanu sodu na flotację solną węgla antracytowego jako modelu substancji bogatych w kerogen, in: Łupek miedzionośny II, Kowalczuk P.B., Drzymala J. (red.), WGGG PWr, Wroclaw, 2016, 195-200

209. A. Luszczkiewicz, P. Karwowski, A. Muszer, J. Drzymala, Separation of Copper Flotation Concentrates into Density Fractions by Means of Polytungstate Aqueous Solution, E3S Web Conf., 8 (2016) 01009, Mineral 
Engineering Conference MEC2016, Swieradow-Zdroj, Poland, September 25-28, 2016, P.B. Kowalczuk and J. Drzymala (Eds.)

210. J. Drzymala, A. Swebodzinska, M. Duchnowska, A. Bakalarz, A. Luszczkiewicz, P.B. Kowalczuk, Preliminary Study on Collectorless Flotation of Chalcocite, Bornite and Copper-Bearing Shale in the Presence of Selected Frothers, E3S Web Conf., 8 (2016) 01031, Mineral Engineering Conference MEC2016, Swieradow-Zdroj, Poland, September 25-28, 2016, P.B. Kowalczuk and J. Drzymala (Eds.)

211. J. Drzymala, P.B. Kowalczuk, Forces and the Young Relationship in the Bubble-Spherical Particle-Liquid System, International Mineral Processing Congress, Quebec City, Canada, Sept. 11-15, 2016

212. P.B. Kowalczuk, J. Drzymala, Selectivity and Power of Poly(propylene glycol) and Poly(ethylene glycol) Alkyl Ethers Frothers in Copper Ore Flotation, International Mineral Processing Congress, Quebec City, Canada, Sept. 11-15, 2016

213. M. Duchnowska, A. Bakalarz, A. Luszczkiewicz, J. Drzymala, P.B. Kowalczuk, A. Konieczny, W. Pawlos, Influence of Selected Frothers on Pre-flotation of the Kupferschiefer Ore, International Mineral Processing Congress, Quebec City, Canada, Sept. 11-15, 2016

214. A. Bakalarz, M. Duchnowska, J. Drzymala, A. Luszczkiewicz, P.B. Kowalczuk, A. Konieczny, W. Pawlos, Flotation of Silver from Copper Ore After Milling in the Presence of Grinding Media of Different Compositions, International Mineral Processing Congress, Quebec City, Kanada, Sept. 11-15, 2016

215. T. Ratajczak, J. Drzymala, P.B. Kowalczuk, Local and Global Assessment of Flotation Kinetics, E3S Web Conf., 8 (2016) 01033, Mineral Engineering Conference MEC2016, Swieradow-Zdroj, Poland, September 25-28, 2016, P.B. Kowalczuk and J. Drzymala (Eds.)

216. M. Duchnowska, A. Bakalarz P.B. Kowalczuk, A. Muszer, J. Drzymala, A. Luszczkiewicz, 2016, Porównanie selektywności wzbogacania w ołów w układzie technologicznym flotacji rudy miedzi w ZWR Lubin, Rudy i Metale Nieżelazne 61

217. P.B. Kowalczuk, J. Zawala, J. Drzymala, 2017. Concentration at the Minimum Bubble Velocity (CMV) for Various Types of Flotation Frothers, Minerals, 7, 118, 1-15 doi:10.3390/min7070118

218. P.B. Kowalczuk, C. Akkaya, M. Ergun, M. Janicki, O. Sahbaz, J. Drzymala, 2017. Water Contact Angle on Corresponding Surfaces of Freshly Fractured Fluorite, Calcite and Mica, Physicochem. Probl. Miner. Process. 53(1), 192-201

219. P.B. Kowalczuk, J. Drzymala, 2017. Selectivity and Power of Frothers in Copper Ore Flotation, Physicochem. Probl. Miner. Process. 53(1), 515-523

220. J. Drzymala, P. Karwowski, K. Borowski, P.M. Pazik, P.B. Kowalczuk, 2017. Próba klasyfikacji łupków Legnicko-Głogowskiego Okręgu Miedziowego na podstawie zawartości węglanów, minerałów ilastych, węgla organicznego oraz miedzi, in: Lupek miedzionośny III, Kowalczuk P.B., Drzymala J. (eds), WGGG PWr, Wroclaw, 52-58

221. B. Kubiak, J. Drzymala, 2017. Wpływ zawartości węgla organicznego na hydrofobowość łupka miedzionośnego, w: Lupek miedzionośny III, Kowalczuk P.B., Drzymala J. (eds), WGGG PWr, Wroclaw, 6468

222. M. Michalski, J. Drzymala, 2017. Stabilność zawiesiny wodnej łupka miedzionośnego w obecności wody kopalnianej, in: Lupek miedzionośny III, Kowalczuk P.B., Drzymala J. (eds), WGGG PWr, Wroclaw, 75-77

223. J. Nowak, J. Drzymala, 2017. Flotacja łupka miedzionośnego w obecności spieniacza, zbieracza oraz depresora w postaci dekstryny, in: Lupek miedzionośny III, Kowalczuk P.B., Drzymala J. (eds), WGGG PWr, Wroclaw, 118-128

224. M. Pokrywka, J. Drzymala, 2017. Flotacja powierzchniowa i hydrofobowość łupka, in: Lupek miedzionośny III, Kowalczuk P.B., Drzymala J. (eds), WGGG PWr, Wroclaw, 129-132

225. J. Trochanowska, J. Drzymala, 2017. Porównanie flotacji łupka i chalkozynu testowanych we flotowniku Hallimonda bez odczynników, w obecności tylko spieniaczy, a także za pomocą heksyloaminy, in: Lupek miedzionośny III, Kowalczuk P.B., Drzymala J. (eds), WGGG PWr, Wroclaw, 133-137

226. J. Drzymala, M. Stodulski, 2017. Moc i kineza heksyloaminy we flotacji łupka miedzionośnego, in: Lupek miedzionośny III, Kowalczuk P.B., Drzymala J. (eds), WGGG PWr, Wroclaw, 2017, 167-171

227. J. Drzymala, T. Ratajczak, P.B. Kowalczuk, 2017. Kinetic Separation Curves Based on Process Rate Considerations, Physicochem. Probl. Miner. Process, 53(2), 983-995 
228. J. Drzymala, 2017. Evaluation of Frothers Based on Properteis of the Solids/Liquid/Gas System, E3S Web Conf., 18, 01009 (2017), Mineral Engineering Conference MEC2017, Wisła, Poland, September 20-23, 2017, A. Chmielarz and A. Wieniewski (Eds.)

229. J. Drzymala, 2017. Universal Equations for Pythagorean and Sauter-type Formulas of Mean Value Calculation and Classification of the Extended Pythagorean Mean, Mining Science, 24:227-235

230. J. Drzymala, Evaluation of Flotation Reagents by Normalization Procedures, Physicochem. Probl. Miner. Process., 54(1), 2018, 182-192

231. J. Drzymala, P.B. Kowalczuk, 2018. Classification of Flotation Frothers. Minerals 8, 53, 1-24

232. R. Michalczuk, J. Drzymala, 2018. Flotacja próżniowa łupka miedzionośnego, in: Lupek miedzionośny IV, Ratajczak, T., Drzymala J. (eds), WGGG PWr, Wroclaw, 57-61

233. D. Bedkowski, J. Drzymala, 2018. Flotacja łupka miedzionośnego w obecności spieniacza i związków glebowych, in: Lupek miedzionośny IV, Ratajczak, T., Drzymala J. (eds), WGGG PWr, Wroclaw, 67-71

234. Sz. Marczuk, J. Drzymala, 2018. Wpływ minerałów ilastych na spieniaczową flotację łupka miedzionośnego, in: Lupek miedzionośny IV, Ratajczak, T., Drzymala J. (eds), WGGG PWr, Wroclaw, 81-88

235. M. Perlak, J. Drzymala, 2018. Spieniaczowa flotacja łupka miedzionośnego po jego traktowaniu silnymi substancjami utleniającymi i redukcyjnymi, in: Lupek miedzionośny IV, Ratajczak, T., Drzymala J. (eds), WGGG PWr, Wroclaw, 89-93

236. K. Kliszowska, J. Drzymala, 2018. Flotacja łupka miedzionośnego w obecności spieniacza i polifosforanu sodu lub krzemianu sodu, in: Lupek miedzionośny IV, Ratajczak, T., Drzymala J. (eds), WGGG PWr, Wroclaw, 100105

237. A. Swebodzińska, J. Drzymala, 2018. Flotacja łupka i bornitu z LGOM w obecności spieniacza oraz wybranych reagentów modyfikujących, in: Lupek miedzionośny IV, Ratajczak, T., Drzymala J. (eds), WGGG PWr, Wroclaw, 106-109

238. P. Muszyński, J. Drzymala, 2018. Odporność łupka miedzionośnego na szok termiczny, in: Lupek miedzionośny IV, Ratajczak, T., Drzymala J. (eds), WGGG PWr, Wroclaw, 122-127

239. J. Drzymala, 2018. Application of Kinetic, Incentive, Limits and Arrheniusan Curves for Flotation Characterization, IOP Conf. Ser.: Mater. Sci., 427, 012011, 1-6

240. J. Drzymala, 2018, Arrheniusan Activation Energy of Separation for Different Parameters Regulating the Process, Physicochem. Probl. Miner. Process. (Special issue to honor J.S. Laskowski) 54(4):1152-1158 